\title{
Sobre autores, conselheiros editoriais e leitores
}

\author{
Harley E.A. Bicas
}

Se ficar o bicho come, se correr o bicho pega. É possível que o dito popular seja invertido, começando com a decisão de correr; ou que troque a alternativa de ser comido pela de ser pêgo; ou, ainda, que mude a ordem e a combinação dos elementos da oração. Não importa, pois o significado é sempre o mesmo e o resultado também. É mais ou menos essa a dificuldade dos editores, procurando administrar a diversidade de pensamentos e opiniões de seus conselheiros em um lado e de autores no outro. Aliás, a regra é precisamente a do conflito, pois é raríssimo que um trabalho receba aprovação imediata e sem a formulação da necessidade de reparos, apontada por dois ou mais juí zes. Os partos são quase todos demorados e por vezes dolorosos. Convém até esclarecer que se estimula o conselheiro ao rigor da análise, mas obviamente temperado com a polidez da forma, de tal modo que as correções endereçadas ao autor sejam pedagógicas e construtivas.

Isto posto (e nem sempre conseguido) voltemos aos casos concretos das agruras dos editores. Um bem difícil é o da comunicação aos autores de que o trabalho deles, pelo menos no modo como apresentado, teve sua publicação rejeitada. É claro que ninguém pode ficar feliz com tal notícia. Uma reprovação - ainda que, mais tarde, possa até chegar a ser encarada como benéfica - traz a sensação de perda, o eventual sentimento de revolta pela possível incompreensão dos julgadores, a frustração de (talvez?) ter que recomeçar, ou abandonar esse projeto. Certamente, a atitude positiva é a de quem, após a queda, "levanta, sacode a poeira e dá a volta por cima", fácil para dizer, difícil no fazer, mas que deve ser incentivada. Afinal, entendimentos errôneos compõem parte das decisões humanas e como os conselheiros editoriais podem errar (e erram!) resta aos autores o direito de recorrer, contornar as fontes de crítica e re-submeter o artigo a novo exame. Realmente, os apontamentos dos conselheiros editoriais sobre inadequações e sobre a conveniência de reparos de artigos analisados são quase todos procedentes; mas ainda quando eventualmente supérfluos ou derivados de interpretações equivocadas, manda a prudência que sejam considerados pelos autores. Pois se o possível engano sobre o teor do texto ocorre a um leitor (que se supõe incumbido de uma análise atenta) mais ainda provavelmente problemático seria o entendimento dos demais.

Outra causa de possível constrangimento dos editores é a do sentimento de um conselheiro editorial de que sua análise e argumentação recomendando a rejeição de um trabalho não tenha sido acatada. Afinal, o trabalho aparece publicado e pode até -- segundo o julgamento dessa pessoa - comprometer o prestígio da revista. Como acontece isso ? Efetivamente, vive-se aí o delicadíssimo assunto de julgamentos e propostas que podem não ser convergentes. Quando ocorrem disparidades de opiniões, sempre há o chamamento de outras análises para ajudar os editores a tomar suas decisões. É claro que o atestado de validade de verdades científicas não se baseia em quantidades de respostas favoráveis a tal ou qual questionamento, nem a publicação de um trabalho tem sua conveniência garantida pela solução democrática de maiorias.

De qualquer modo, tanto pela qualidade como também pela quantidade de argumentos e por suas ressonâncias, faz-se o convencimento de um editor; que, quando em dúvida, recorre a seus pares para a tomada de decisões. E embora, no processo, os preconceitos possam ficar superados, não há infalibilidade assegurada. Enfim, injustiças podem ser perpretadas: seja no sentido de impedir a vinda à luz de uma idéia boa, ainda que heterodoxa, seja no de permitir que outra, falha, apareça publicada.

Na história da ciência são numerosos e clássicos os casos de intolerância, resistência e reprovação a idéias que, depois, mostraram-se verdadeiras. E, por outro lado, os de apoio a outras que, adiante, feneceram. Embates e falhas fazem parte dos sistemas epistêmicos e editores, como seus agentes, não ficam livres dessas vicissitudes. Esterilizar propostas inovadoras (pela simples aplicação da ortodoxia) parece mais nocivo ao desenvolvimento da ciência do que permitir suas submissões a análises mais amplas, as dos leitores (e aí, curiosamente, volta a questão da "quantidade" no julgamento de validade dos assuntos). Esse é um dos métodos disponíveis de correção de rumos de eventuais enganos editoriais: a exposição das idéias à experiência e à análise de outros membros da comunidade de conhecimentos.

Para esse fim, um dos espaços disponíveis numa revista científica, infelizmente ainda muito pouco utilizado entre nós é o das Cartas aos Editores, em que o debate franco e livre entre idéias, a manifestação de opiniões, as críticas favoráveis ou desfavoráveis a um artigo podem ser feitas. Essa importantíssima oportunidade de interações de leitores com a revista, embora desde sempre incentivada deverá receber, doravante, estímulos especiais. Com os quais se espera que se desenvolva e se consolide como contribuição adicional ao aprimoramento científico em nosso meio. 